
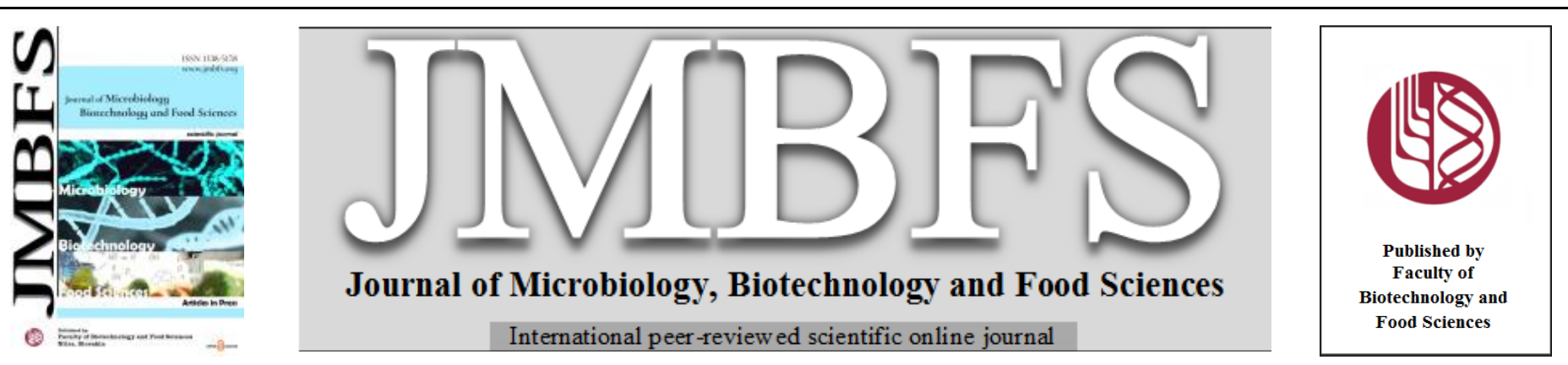

\title{
STUDY OF THE PHENOLIC COMPOSITION AND ANTIOXIDANT ACTIVITY OF WHITE AND RED WINES OBTAINED FROM INTRODUCED, LOCAL AND HYBRID GRAPEVINE VARIETIES FROM THE REGION OF CENTRAL NORTHERN BULGARIA
}

\author{
Dimitar Dimitrov ${ }^{*}$, Tatyana Yoncheva ${ }^{1}$, Vanyo Haygarov ${ }^{1}$ \\ $\operatorname{Address(es):~}$ \\ ${ }^{1}$ Agricultural Academy, Department of Selection, Enology and Chemistry, Institute of Viticulture and Enology, 1 Kala Tepe str., 5800, Pleven, Bulgaria, phone \\ number: +359885540245 .
}

*Corresponding author: dimitar robertov@abv.bg

https://doi.org/10.55251/jmbfs.5541

\section{ARTICLE INFO}

Received 14. 11. 2021

Revised 21. 1. 2022

Accepted 25. 1. 2022

Published 1. 6. 2022

Regular article

open $\mathcal{O}$ access

\begin{abstract}
Study on the phenolic composition and antioxidant activity of white and red wines obtained from introduced (Chardonnay, Cabernet Sauvignon), local (Dimyat, Gamza) and hybrid (Druzhba, Rubin) varieties was performed. The wines had optimal chemical parameters. Almost identical total phenolic compounds (TPC) content $\left(700.00 \pm 0.0 .000 \mathrm{mg} / \mathrm{dm}^{3}\right.$ and $\left.703.33 \pm 5.773 \mathrm{mg} / \mathrm{dm}^{3}\right)$ in the white wines of the introduced Chardonnay variety and the local Dimyat was found. The wine of the introduced Cabernet Sauvignon showed the highest quantitative presence of TPC $\left(1666.66 \pm 5.773 \mathrm{mg} / \mathrm{dm}^{3}\right)$ from the red wines group. Chardonnay wine showed the highest content of flavonoid phenolic compounds (FPC) $\left(769.84 \pm 1.833 \mathrm{mg} / \mathrm{dm}^{3}\right)$, and for the red wines FPC content dominated quantitatively in Rubin $\left(2532.40 \pm 49.938 \mathrm{mg} / \mathrm{dm}^{3}\right)$. The wine of the introduced Chardonnay also showed the highest content of non-flavonoid phenolic compounds (NPC) $\left(115.78 \pm 0.325 \mathrm{mg} / \mathrm{dm}^{3}\right)$, and in the red wines Gamza $\left(235.63 \pm 0.498 \mathrm{mg} / \mathrm{dm}^{3}\right)$ was distinguished by this indicator. The quantitative presence of anthocyanins in the studied red wines followed the order wine - introduced variety $>$ wine - hybrid variety $>$ wine - local variety. The highest antioxidant activity (AA) in white wines was found in Chardonnay. Gamza and Cabernet Sauvignon red wines showed a close percentage of radical scavenging activity, but it was slightly higher in the wine of the local Gamza variety. There was a correlation between the antioxidant activity of red wines and the content of NPC in them, respectively: NPC (AA) Gamza > NPC (AA) Cabernet Sauvignon > NPC (AA) Rubin. The white and red wines from introduced, local and hybrid grapevine varieties from the region of Pleven, Central Northern Bulgaria showed good and balanced phenolic accumulation capacity, resulted in optimal ability for in vitro elimination of free DPPH radicals.
\end{abstract}

Keywords: antioxidant activity, phenols, DPPH, wines, grapevine varieties, chemical composition, free radicals

\section{INTRODUCTION}

The preventive biological effect of antioxidants associated with the elimination of the so-called reactive oxygen species (free radicals) capable of initiating mutations in cellular structures and inducing significant diseases is well known (Hertog $\boldsymbol{e t}$ al., 1995; Srivastava and Kumar, 2015). Nowadays the attention of the scientific community in the field of food science becoming increasingly concentrated in defining the antioxidant capacity and activities of foods and beverages. The study of Renaud and Lorgeril (1992), known as the "French paradox", found a low incidence of cardiovascular diseases in men between the ages of 54 and 65, who moderate consuming red wine, and despite the high consumption of fats from foods with animal origin. It gives the start and impetus for extensive and large-scale research on the wine healthy activities.

The antioxidant effect of wine is mainly due to its phenolic complex, consisting of natural polyphenolic substances (especially catechins), as well as some oxyacids and products of their metabolism, ascorbic and dioxyfumaric acids (Velkov, 1996) The content of phenolic compounds in wine is determined by the phenolic stock of the particular grapevine variety and the applied technology (Ivanov, 1981; Chobanova, 2012). According to Waterhouse (2002), the total content of nonflavonoid phenolic compounds in young white wines reach $164.50 \mathrm{mg} / \mathrm{dm}^{3}$, while after their aging the phenols increase to $245.50 \mathrm{mg} / \mathrm{dm}^{3}$. Of the flavonoid phenolic compounds in white wines, only flavanol monomers and proanthocyanidins are found. According to Waterhouse (2002), red wines accumulate significantly higher amounts of total non-flavonoid phenolic compounds $\left(232.00 \mathrm{mg} / \mathrm{dm}^{3}\right.$. young wines; $1285.00 \mathrm{mg} / \mathrm{dm}^{3}$ - aged red wines) than white wines. From the group of flavonoid phenolic compounds flavonoid monomers decrease in the process of red wines aging (from $200.00 \mathrm{mg} / \mathrm{dm}^{3}$ to $100.00 \mathrm{mg} / \mathrm{dm}^{3}$ ), but in both cases (in young and aged red wines) they exceed tens of times the amounts found in white wines. A study of the total phenolic composition of wines from two red varieties and one white from Turkey (Cabernet Sauvignon, Kalecik Karası and Narinche, respectively) found a variation of the total phenolic compounds of $217.06 \mathrm{mg}$.
GAE. $\mathrm{l}^{-1}$ to $1366.21 \mathrm{mg}$. GAE. $\mathrm{l}^{-1}$ (Baydar et al., 2011). Shadidi and Nazck (1995) found that the content of total phenolic compounds in red wines ranges from $1000.00-4000.00 \mathrm{mg} / \mathrm{dm}^{3}$, and in white from $50.00-2000.00 \mathrm{mg} / \mathrm{dm}^{3}$. Li et al (2009) found that the content of total phenolic compounds in red wines ranged from $1402.00-3130.00 \mathrm{mg} / \mathrm{dm}^{3}$ and significantly exceed that found in white wines (189.00 - $\left.495.00 \mathrm{mg} / \mathrm{dm}^{3}\right)$. Nistor et al. (2015) examined the content of anthocyanins and total phenolic compounds in wines of Cabernet Sauvignon and Pinot Noir varieties from three consecutive harvests (2011, 2012 and 2013) produced in two different wine-cellars. The team found a variation in the content of anthocyanins in the wines of the first group of $341.70 \pm 34.32 \mathrm{mg} / \mathrm{dm}^{3}-479.30$ $\pm 46.64 \mathrm{mg} / \mathrm{dm}^{3}$ (Cabernet Sauvignon) and $311.40 \pm 15.53 \mathrm{mg} / \mathrm{dm}^{3}-346.50 \pm$ $36.05 \mathrm{mg} / \mathrm{dm}^{3}$ (Pinot Noir). The content of anthocyanins in the analyzed wines of the second producer is in the range of $258.80 \pm 10.29 \mathrm{mg} / \mathrm{dm}^{3}-348.10 \pm 6.43$ $\mathrm{mg} / \mathrm{dm}^{3}$ (Cabernet Sauvignon) and $214.20 \pm 14.00 \mathrm{mg} / \mathrm{dm}^{3}-298.30 \pm 11.53$ $\mathrm{mg} / \mathrm{dm}^{3}$ (Pinot Noir). With regard to the found total phenolic compounds in the first group, a variation of $2072.00 \pm 81.38 \mathrm{mg} / \mathrm{dm}^{3}-2758.00 \pm 149.90 \mathrm{mg} / \mathrm{dm}^{3}$ (Cabernet Sauvignon) and $1814.00 \pm 92.51 \mathrm{mg} / \mathrm{dm}^{3}-2695.00 \pm 76.46 \mathrm{mg} / \mathrm{dm}^{3}$ (Pinot Noir) is found. For the red wines of the second group the total phenolic content is found in the range of $1986.00 \pm 163.50 \mathrm{mg} / \mathrm{dm}^{3}-2531.00 \pm 77.76$ $\mathrm{mg} / \mathrm{dm}^{3}$ (Cabernet Sauvignon) and $1752.00 \pm 94.90 \mathrm{mg} / \mathrm{dm}^{3}-2214.00 \pm 35.56$ $\mathrm{mg} / \mathrm{dm}^{3}$ (Pinot Noir).

The phenolic composition of wines is mainly and closely related to their antioxidant activity.

Baydar et al. (2011) conducted a study to determine the radical-capturing activity of wines from white (Narinche) and red varieties (Cabernet Sauvignon and Kalecik Karas1), using the DPPH method. The study found a high percentage of antiradical activity in red wines $(84.01 \%$ for Kalecik Karası and $81.34 \%$ for Cabernet Sauvignon), compared to the low values of this indicator in white wine $-19.10 \%$ Katalinić et al., (2004) investigated the antioxidant activity (via DPPH • method) of 6 red wines (Dingač, Babić, Cabernet Sauvignon, Faros, Faros - aged in barrel and Merlot) and 4 white (Maraština, Pošip, Traminak and Graševina) from Croatia, 
obtained from different harvests. For red wines, the team found a variation from $54.60 \%$ (Faros) to $82.60 \%$ for Dingač wine. The Cabernet Sauvignon wine showed close antioxidant activity $(82.20 \%)$ to that of Dingač. In the analysis of the four white wines with the highest $\mathrm{DPPH} \bullet$ radical-capturing activity is characterized the wine of the variety Maraština $(16.16 \%)$, and with the lowest of the variety Traminak (10.30\%). Marković et al. (2015) conducted a study on the tota phenolic composition and antioxidant activity (via DPPH •) of 11 white wines from the trade market, obtained from the local variety Žilavka from Bosnia and Herzegovina. The team found antioxidant capacity from $28.80 \%$ to $70.20 \%$.

The aim of the present study was to determine the phenolic composition and antioxidant activity of white and red wines obtained from introduced, local and hybrid grapevine varieties from the region of Pleven, Central Northern Bulgaria.

\section{MATERIAL AND METHODS}

\section{Grapevine varieties}

The study was conducted at the Institute of Viticulture and Enology (IVE) - Pleven (Central Northern Bulgaria). The subject of the study were white and red wines, harvested in 2020, of three white and three red grapevine varieties - introduced, local and hybrid:

\section{Introduced varieties}

These varieties had a control role in research.

- Chardonnay - white grapevine variety originating from Burgundy and Champagne, France (Sweet, 2007). For the region of Pleven it ripens around the middle of September. It accumulates sugars quickly, maintaining a relatively high titratable acidity (7.0-9.0 g/dm $\left.{ }^{3}\right)$ at high sugar content (20-24\%) (Radulov $\boldsymbol{e t}$ al. 1992; Roychev, 2012).

- Cabernet Sauvignon - red grapevine variety originating from the Bordeaux region in southwestern France (Sweet, 2008). For the region of Pleven it ripens in the second half of September. At technological maturity, grapes can accumulate sugars up to $21-24 \%$, and its titratable acidity is relatively high $\left(6.5-9.0 \mathrm{~g} / \mathrm{dm}^{3}\right)$ (Radulov et al., 1992; Roychev, 2012).

\section{Local varieties}

- Dimyat - old local, Bulgarian, white grapevine variety. Late ripening, as for the region of Pleven it ripens in the second half of September. Grapes accumulate sugars of $19-21 \%$ at titratable acids $6.0-7.0 \mathrm{~g} / \mathrm{dm}^{3}$ (Radulov et al., 1992; Roychev, 2012).

- Gamza - red local grapevine variety. Its grapes ripen in the second half of September. Sugar accumulation is in the range of $19-21 \%$ at titratable acids 5.9$8.9 \mathrm{~g} / \mathrm{dm}^{3}$ (Radulov et al., 1992; Roychev, 2012).

\section{Hybrid varieties}

- Druzhba - white variety, created by an international team of IVE - Pleven and VNIIH - Novocherkassk (Russia), through complex interspecific hybridization (Muscat Hamburg x Seiv Villar 12 375) x (Zarya Severa x Muscat Hamburg) and approved in 1983. Included in the Official Variety List of Bulgaria in 2012. At technological maturity the sugar content is $19-21 \%$, with titratable acids $6.5-7.5$ $\mathrm{g} / \mathrm{dm}^{3}$ (Radulov et al., 1992; Roychev, 2012).

- Rubin - a hybrid red grapevine variety. It was obtained by intraspecific hybridization by crossing Nebiolo x Syrah (Petkov, 1977) and approved in 1961 Included in the Official Variety List of Bulgaria in 2012. The variety is medium ripening, and for the region of Pleven ripens in the first half of September. The variety has a high sugar accumulation capacity - 22-24\% and more, with titratable acids 5.5-6.0 g/dm ${ }^{3}$ (Radulov et al., 1992; Roychev, 2012).

\section{Vinification}

The grape harvest of the studied varieties is carried out upon reaching technological maturity. The grapes, in the amount of $30 \mathrm{~kg}$, of each variety were processed in the Experimental Wine Cellar of IVE - Pleven, in the conditions of microvinification, according to the classical schemes for production of white and red wines (Yankov, 1992).

\section{- Production of white wines}

The technological operations include: Crushing the grapes $>$ Destamming Pressing Sulphitation $\left(50 \mathrm{mg} / \mathrm{dm}^{3} \mathrm{SO}_{2}\right)$ Clarification of the must and decanting Alcoholic fermentation (dry wine yeast Saccharomyces cerevisiae 20 $\mathrm{g} / \mathrm{hl}$; temperature $\left.20^{\circ} \mathrm{C}\right)>$ Racking $>$ Additional sulphitation $>$ Storage

- Production of red wines

The technological operations include: Crushing Destemming Sulphitation $\left(50 \mathrm{mg} / \mathrm{kg} \mathrm{SO} \mathrm{SO}_{2}\right)$ Alcoholic fermentation (dry wine yeast Saccharomyces cerevisiae $20 \mathrm{~g} / \mathrm{hl}$; temperature $28^{\circ} \mathrm{C}$ ) Separation from solids $>$ Additional sulphitation Storage

Chemical analysis of the obtained white and red wines

The analyzes were performed according to the generally accepted methods in wine practice (Ivanov et al., 1979).

- Determination of sugar content $\left(\mathrm{g} / \mathrm{dm}^{3}\right)$ - Shoorl method;

- Determination of the alcohol content (vol. \%) - distillation method using a Gibertini apparatus with a densimeter, by determining the density of a nonalcoholic sample;

- Determination of titratable acids of wine (TA, g/dm ${ }^{3}$ ) - by titration with $\mathrm{NaOH}$;

- Determination of the $\mathrm{pH}$ - with $\mathrm{pH}$ meter;

- Determination of total extract - by densimeter (Gibertini).

\section{Determination of the phenolic content of the wines}

- Determination of total phenolic compounds (TPC) - according to the method of Singleton et Rossi (Chobanova, 2012);

- Determination of the content of flavonoid phenolic compounds (FPC);

- Determination of the content of non-flavonoid phenolic compounds (NPC);

- Determination of anthocyanin content - method of Singleton et Rossi by changing the $\mathrm{pH}$ (Chobanova, 2012) * the analysis was performed only for red wines;

\section{Determination of antioxidant (DPPH) activity of the wines}

The antioxidant activity was determined according to the method of Wang $\boldsymbol{e t}$ al. 1996 as antiradical activity against a stable product DPPH (2,2-diphenyl-1picrylhydrazyl) (Sigma Aldrich, Germany). The wine samples were diluted to a total extract of $600.00 \mathrm{mg} / \mathrm{dm}^{3}$ and $400.00 \mathrm{mg} / \mathrm{dm}^{3}$ and the analysis was carried out on the samples thus diluted, respectively marked as TE $=600.00 \mathrm{mg} / \mathrm{dm}^{3}$ and TE $=400.00 \mathrm{mg} / \mathrm{dm}^{3}$.

\section{Statistical data processing}

The statistical analysis of the data included the determination of the standard deviation $( \pm \mathrm{SD})$, with three repetitions for each analysis. The determination of the indicator was realized by the program Excel 2007 from the Microsoft Office Package (Microsoft Corporation, USA).

\section{RESULTS AND DISCUSSION}

The data on the main chemical indicators of the wines obtained are presented in Table 1 .

Table 1 Chemical indicators of the studied wines

\begin{tabular}{|c|c|c|c|c|c|}
\hline WINES & $\begin{array}{c}\text { Alcohol content, } \\
\text { vol. } \% \\
\end{array}$ & $\begin{array}{c}\text { Total extract, } \\
\mathrm{g} / \mathrm{dm}^{3}\end{array}$ & $\begin{array}{l}\text { Sugars, } \\
\text { g/dm }^{3}\end{array}$ & $\begin{array}{c}\text { Titratable acids, } \\
\text { g/dm }^{3}\end{array}$ & pH \\
\hline $\begin{array}{l}\text { CHARDONNAY } \\
\text { Introduced white grapevine variety }\end{array}$ & $12.83 \pm 0.030$ & $23.53 \pm 0.115$ & $2.03 \pm 0.080$ & $8.32 \pm 0.075$ & $3.06 \pm 0.010$ \\
\hline $\begin{array}{l}\text { DIMYAT } \\
\text { local white grapevine variety }\end{array}$ & $12.17 \pm 0.005$ & $23.93 \pm 0.665$ & $7.35 \pm 0.130$ & $6.87 \pm 0.040$ & $3.33 \pm 0.005$ \\
\hline $\begin{array}{l}\text { DRUZHBA } \\
\text { hybrid white grapevine variety }\end{array}$ & $14.86 \pm 0.055$ & $20.96 \pm 0.349$ & $1.56 \pm 0.161$ & $5.72 \pm 0.046$ & $3.44 \pm 0.005$ \\
\hline $\begin{array}{l}\text { CABERNET SAUVIGNON } \\
\text { introduced red grapevine variety }\end{array}$ & $13.35 \pm 0.020$ & $26.56 \pm 0.057$ & $0.96 \pm 0.057$ & $5.35 \pm 0.116$ & $3.88 \pm 0.000$ \\
\hline $\begin{array}{l}\text { GAMZA } \\
\text { local red grapevine variety }\end{array}$ & $14.29 \pm 0.025$ & $25.63 \pm 0.057$ & $1.46 \pm 0.277$ & $4.83 \pm 0.229$ & $3.82 \pm 0.000$ \\
\hline $\begin{array}{l}\text { RUBIN } \\
\text { hybrid red grapevine variety }\end{array}$ & $13.80 \pm 0.017$ & $24.23 \pm 0.115$ & $1.30 \pm 0.196$ & $6.37 \pm 0.075$ & $3.55 \pm 0.005$ \\
\hline
\end{tabular}

The highest alcohol content in white wines was found in the wine from Druzhba variety $(14.86 \pm 0.025 \mathrm{vol} \%$ ), while in red wines this indicator was the highest in
Gamza (14.29 \pm 0.025 vol. \%). The wines had good extractivity, as a rule the total extract of the reds was higher than that of the whites. In the latter group Druzhba 
showed the highest extractivity $\left(20.96 \pm 0.349 \mathrm{~g} / \mathrm{dm}^{3}\right)$. The other two white wines showed similar values on this indicator. Red wine extract was the highest in Cabernet Sauvignon $\left(26.56 \pm 0.057 \mathrm{~g} / \mathrm{dm}^{3}\right)$. Regarding the presence of residual sugars, almost all wines were categorized as dry - with a sugar content up to 4.0 $\mathrm{g} / \mathrm{dm}^{3}$ (Chobanova, 2012). The only exception was Dimyat wine, which had a higher residual sugar $\left(7.35 \pm 0.130 \mathrm{~g} / \mathrm{dm}^{3}\right)$, defined it as semi-dry.

According to Chobanova (2012), the optimal titratable acidity for dry wines varies from 5.00 to $9.00 \mathrm{~g} / \mathrm{dm}^{3}$. In the present study, a variation in this indicator for white wines from $5.72 \pm 0.046 \mathrm{~g} / \mathrm{dm}^{3}$ (Druzhba) to $8.32 \pm 0.075 \mathrm{~g} / \mathrm{dm}^{3}$ (Chardonnay) was found. For red wines it was lower and occupied the range from $4.83 \pm 0.029 \mathrm{~g} / \mathrm{dm}^{3}$ (Gamza) to $6.37 \pm 0.075 \mathrm{~g} / \mathrm{dm}^{3}$ (Rubin). The titratable acidity found in the studied wines was typical for quality dry wines.

The normal $\mathrm{pH}$ wine values range from 2.8 to 3.8 (Chobanova, 2012). The study of the three white wines showed a variation on this indicator from $3.06 \pm 0.010$ (Chardonnay) to $3.44 \pm 0.005$ (Druzhba), for the red ones it was from $3.55 \pm 0.005$ (Rubin) to $3.88 \pm 0.000$ (Cabernet Sauvignon). All wines showed normal pH values.

The data for the content of total phenolic compounds (TPC) in the analyzed wines are presented in Figure 1.

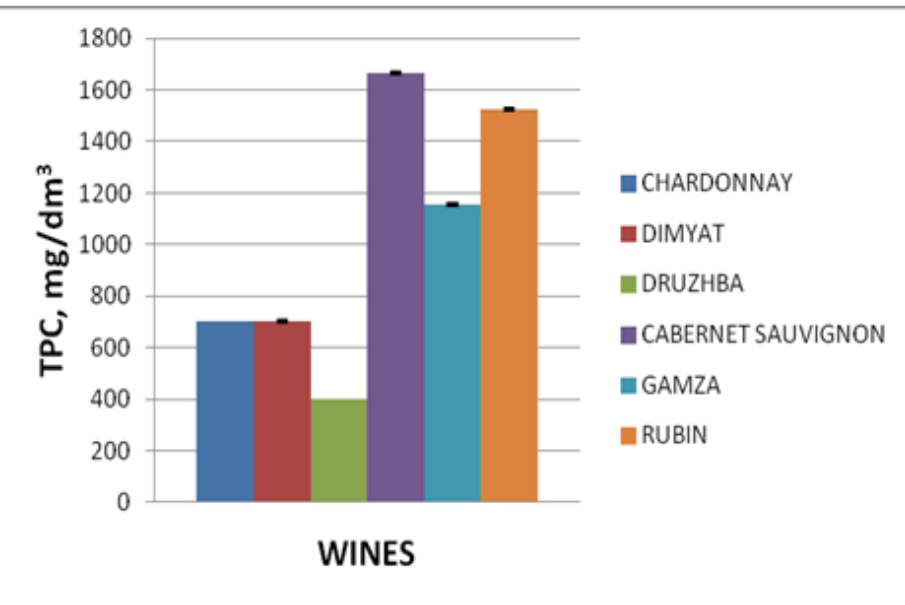

Figure 1 Content of total phenolic compounds (TPC) in white and red wines of the studied varieties

As can be seen from the results presented in the figure, that red wines showed higher content of TPC than white wines. This is a normal trend due to purely technological reasons - fermentation of grape juice (for white wines) and fermentation with solid parts (for red wines).

The data regarding the established content of TPC in white wines showed almost identical concentration of phenols in the wine of the introduced Chardonnay variety and the local Dimyat $\left(700.00 \pm 0.0 .000 \mathrm{mg} / \mathrm{dm}^{3}\right.$ and $703.33 \pm 5.773$ $\mathrm{mg} / \mathrm{dm}^{3}$, respectively). The wine of the Druzhba hybrid showed lower levels of TPC $\left(400.00 \pm 0.000 \mathrm{mg} / \mathrm{dm}^{3}\right)$ compared to the wines of the other two varieties. In the red wines the content of TPC was the highest in the wine of the control introduced variety Cabernet Sauvignon $\left(1666.66 \pm 5.773 \mathrm{mg} / \mathrm{dm}^{3}\right)$. It was followed by the wine of the hybrid variety Rubin $\left(1526.66 \pm 5.773 \mathrm{mg} / \mathrm{dm}^{3}\right)$, and the lowes content of TPC was found in Gamza $\left(1153.33 \pm 5.773 \mathrm{mg} / \mathrm{dm}^{3}\right)$. The data obtained in the present study on the content of TPC in white and red wines correlated with the results reported for this indicator in other studies (Shadidi and Nazck, 1995; Li et al., 2009; Nistor et al., 2015).

The data of the detected amount of flavonoid phenolic compounds (FPC) in the analyzed wines are presented in Figure 2.

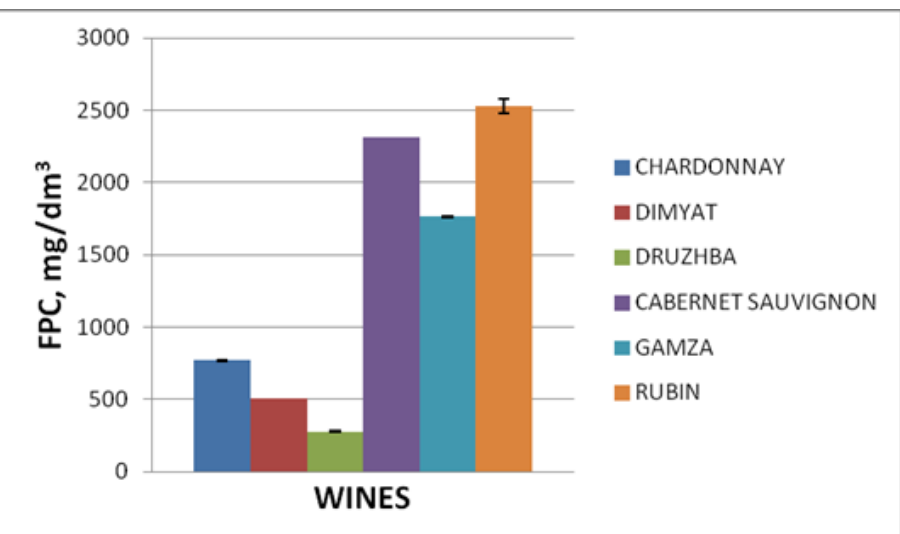

Figure 2 Content of flavonoid phenolic compounds (FPC) in white and red wines of the studied varieties
The trend in the amount of FPC was the same as in TPC - higher total amount in red wines compared to white ones. In white wines, the highest presence of FPC was found in the wine of the introduced control Chardonnay variety (769.84 \pm $\left.1.833 \mathrm{mg} / \mathrm{dm}^{3}\right)$, followed by the local Dimyat $\left(506.85 \pm 1.044 \mathrm{mg} / \mathrm{dm}^{3}\right)$ and the lowest was the content of FPC in the wine of the hybrid Druzhba $(278.61 \pm 1.251$ $\left.\mathrm{mg} / \mathrm{dm}^{3}\right)$.

In the analysis of the FPC results in red wines, the quantitative dominance of the Cabernet Sauvignon control $\left(2314.44 \pm 2.045 \mathrm{mg} / \mathrm{dm}^{3}\right)$ was absent. It has been replaced by the Rubin hybrid $\left(2532.40 \pm 49.938 \mathrm{mg} / \mathrm{dm}^{3}\right)$, which made this wine the richest of FPC from the red group. The wine of the local variety Gamza $\left(1765.53 \pm 4.015 \mathrm{mg} / \mathrm{dm}^{3}\right)$ was characterized by the lowest FPC content.

The results regarding the presence of NPC in the studied wines are presented in Figure 3.

The trend in the content of NPC in white wines was the same as that observed for FPC. The wine of the control introduced Chardonnay variety $(115.78 \pm 0.325$ $\mathrm{mg} / \mathrm{dm}^{3}$ ) was characterized by the highest content of NPC. The wine of the local variety Dimyat showed an NPC content of $102.78 \pm 0.177 \mathrm{mg} / \mathrm{dm}^{3}$, slightly lower than the control. The lowest content according to this indicator $(78.37 \pm 0.344$ $\mathrm{mg} / \mathrm{dm}^{3}$ ) was found in the wine of the hybrid variety Druzhba. It was lower than the other two wines studied.

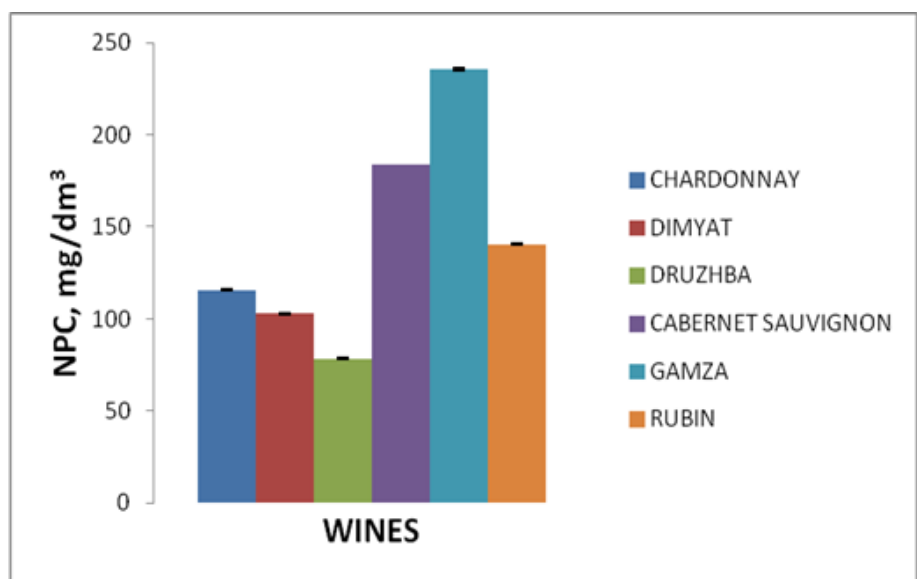

Figure 3 Content of non-flavonoid phenolic compounds (NPC) in white and red wines of the studied varieties

In red wines, the highest accumulation of NPC was observed in Gamza wine $\left(235.63 \pm 0.498 \mathrm{mg} / \mathrm{dm}^{3}\right)$. It was followed by the wine of the control introduced variety Cabernet Sauvignon $\left(183.70 \pm 0.140 \mathrm{mg} / \mathrm{dm}^{3}\right)$. The lowest (significantly lower than that of Gamza) content of NPC was found in the wine of the hybrid variety Rubin $\left(140.63 \pm 0.406 \mathrm{mg} / \mathrm{dm}^{3}\right)$.

The content of anthocyanins in red wines is presented in Figure 4.

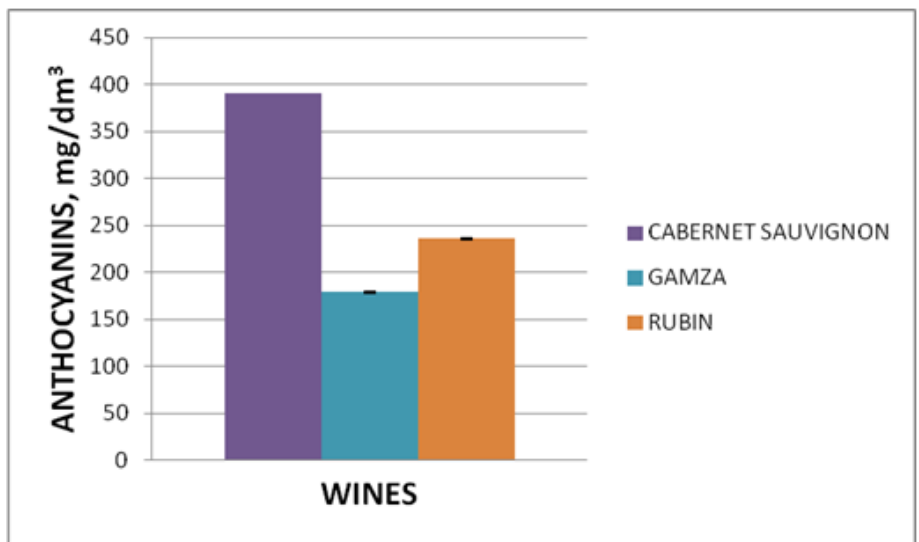

Figure 4 Content of anthocyanins in red wines of the studied varieties

The anthocyanins are red pigments. After vinification in young red wines, they are accumulate in the amount of $200.00-500.00 \mathrm{mg} / \mathrm{dm}^{3}$ (Chobanova, 2012). In the present study, the highest content of anthocyanins was found in the wine of the control introduced variety Cabernet Sauvignon $\left(390.85 \pm 0.374 \mathrm{mg} / \mathrm{dm}^{3}\right)$. It was lower in Rubin $\left(235.60 \pm 0.636 \mathrm{mg} / \mathrm{dm}^{3}\right)$ and the lowest in the wine of the local variety Gamza $\left(178.88 \pm 0.425 \mathrm{mg} / \mathrm{dm}^{3}\right)$. The established anthocyanin conten followed the order: wine-introduced variety > wine-hybrid variety > wine-loca variety. The anthocyanin content data obtained in the present study correlated with the results from the study of Nistor et al. (2015).

Figures 5, 6 and 7 show the results of the established antioxidant activity of the studied white wines. 
$T E=600.00 \mathrm{mg} / \mathrm{dm}^{3}$

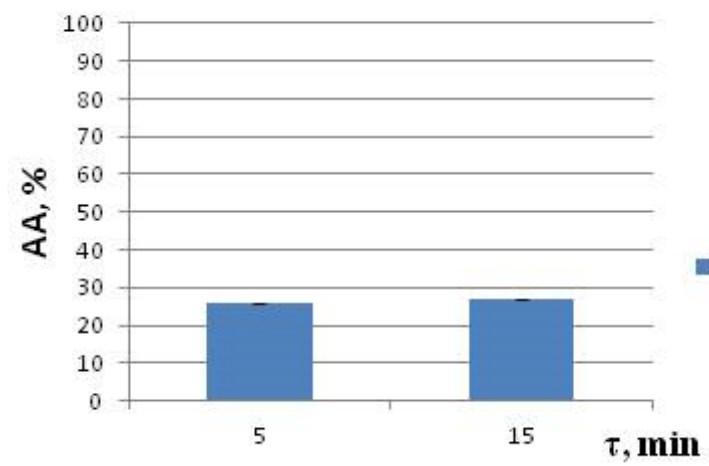

$\mathrm{TE}=400.00 \mathrm{mg} / \mathrm{dm}^{3}$

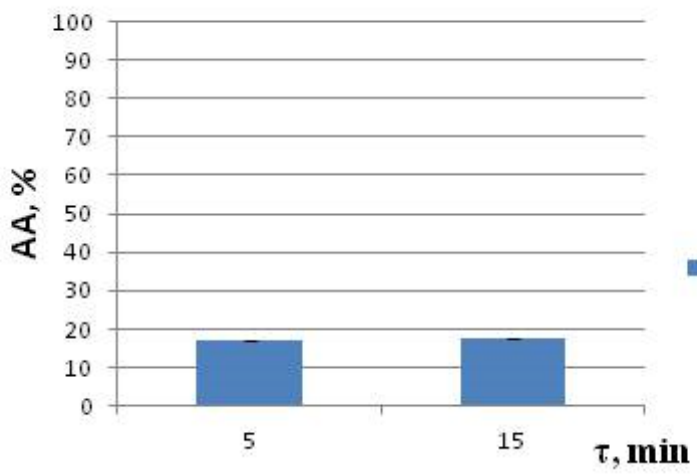

Figure 5 Antioxidant activity of white wine of the control introduced Chardonnay variety at TE $=600.00 \mathrm{mg} / \mathrm{dm}^{3} \mathrm{and} \mathrm{TE}=400.00 \mathrm{mg} / \mathrm{dm}$
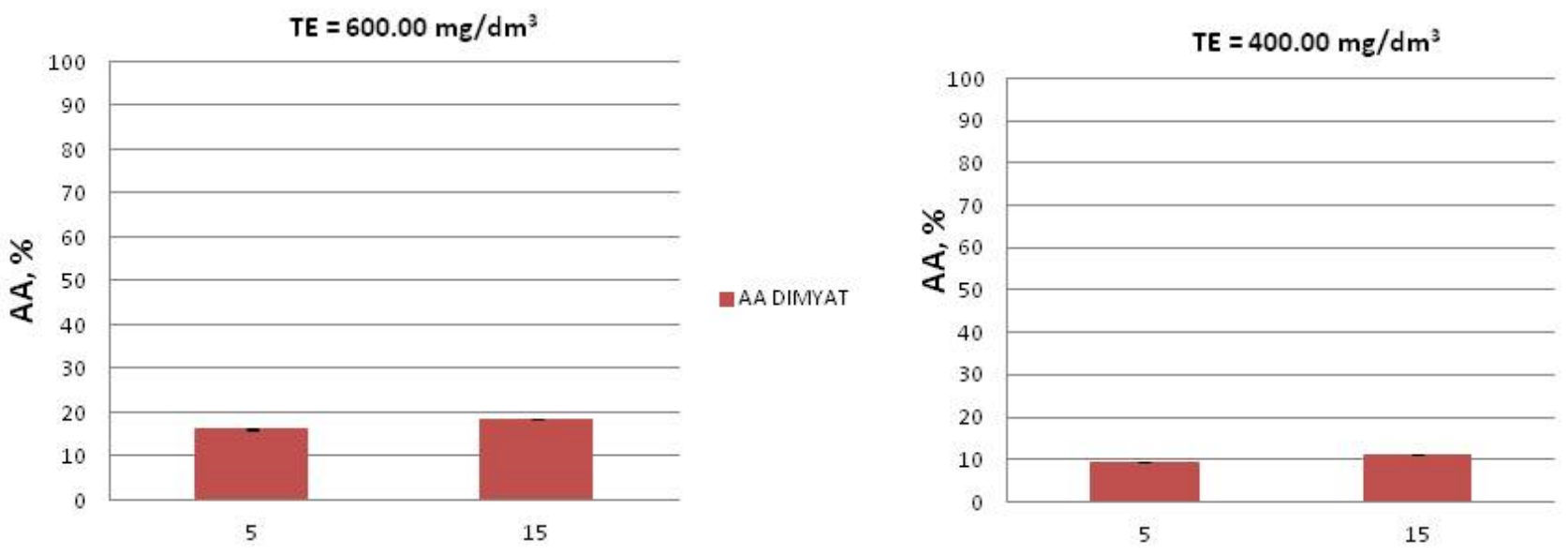

Figure 6 Antioxidant activity of white wine of the local variety Dimyat at TE $=600.00 \mathrm{mg} / \mathrm{dm}^{3}$ and TE $=400.00 \mathrm{mg} / \mathrm{dm}{ }^{3}$

$\mathrm{TE}=600.00 \mathrm{mg} / \mathrm{dm}^{3}$

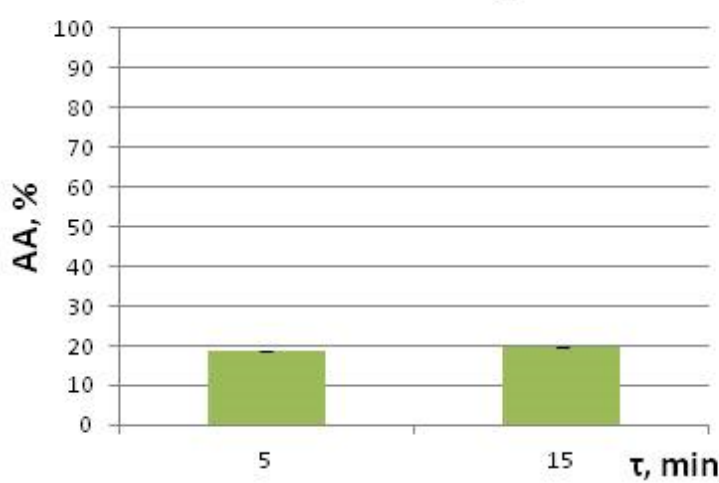

$\mathrm{TE}=400.00 \mathrm{mg} / \mathrm{dm}^{3}$

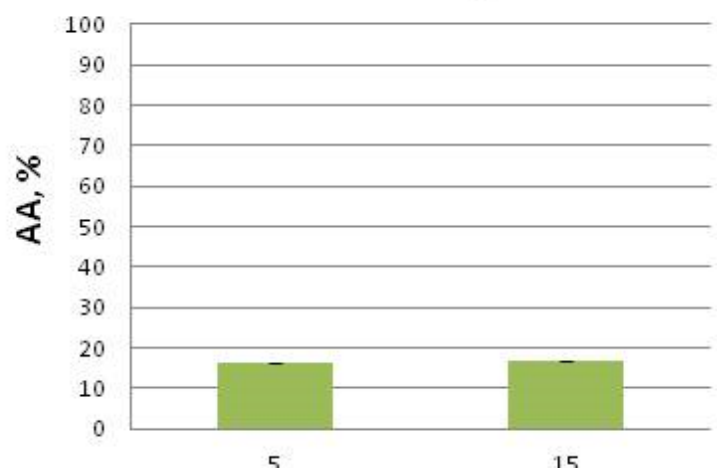

Figure 7 Antioxidant activity of white wine of the hybrid variety Druzhba at TE $=600.00 \mathrm{mg} / \mathrm{dm}^{3} \mathrm{and} \mathrm{TE}=400.00 \mathrm{mg} / \mathrm{dm}{ }^{3}$

The wine of the control introduced Chardonnay variety (Fig. 5) showed the highest antioxidant activity of the three studied wines. At TE $=600.00 \mathrm{mg} / \mathrm{dm}^{3}$ activity at 5 th min from $25.98 \pm 0.011 \%$ was reported and at 15 th min from the moment of radical addition it slightly increased to $27.00 \pm 0.005 \%$. When the concentration of the extract was reduced to $400.00 \mathrm{mg} / \mathrm{dm}^{3}$ in Chardonnay wine, lower antiradica activity was reported, respectively at 5 th $\min$ from $16.98 \pm 0.080 \%$ and at 15 th $\min$ from $17.68 \pm 0.017 \%$.

The difference in the established anti-radical activity of the wines from the local and hybrid variety was small. Slightly higher activity showed the wine of the hybrid variety Druzhba. At TE $=600.00 \mathrm{mg} / \mathrm{dm}^{3}$ in 5 th min of reaction, Druzhba wine showed elimination of the DPPH radicals of $18.62 \pm 0.000 \%$. At 15 th min of reaction it increased very slightly to $19.79 \pm 0.017 \%$. At TE $=400.00 \mathrm{mg} / \mathrm{dm}^{3}$, a decrease in antioxidant activity was observed but it was small. An activity of 16.29 $\pm 0.010 \%$ was detected in 5 th $\mathrm{min}$ of reaction. A slight, almost insignificant increase $(16.67 \pm 0.025 \%)$ was observed at 15 th $\mathrm{min}$.
The wine of the local variety Dimyat showed the lowest antioxidant activity, but it was only approximately $2 \%$ different from that of Druzhba. Thus, at TE $=600.00$ $\mathrm{mg} / \mathrm{dm}^{3}$ at 5 th minutes of reaction in Dimyat, an antiradical activity of $16.15 \pm$ $0.010 \%$ was found. At 15 th $\mathrm{min}$ it increased to $18.31 \pm 0.011 \%$. At TE $=400.00$ $\mathrm{mg} / \mathrm{dm}^{3}$ a decrease was observed, as at 5 th min antioxidant activity of $9.45 \pm 0.061$ $\%$ was registered, and at 15 th $\mathrm{min}$ it was slightly higher $(11.32 \pm 0.005 \%)$.

The established results correlated with the studies of Katalinić et al. (2004) and Marković et al. (2015), which analyzed white wines and found variation in their antioxidant activity, respectively from $10.30 \%-16.16 \%$ and from $28.80 \%$ $70.20 \%$.

The data on the established antioxidant activity in the studied red wines are presented in figures 8,9 and 10 . 
$\mathrm{TE}=600.00 \mathrm{mg} / \mathrm{dm}^{3}$

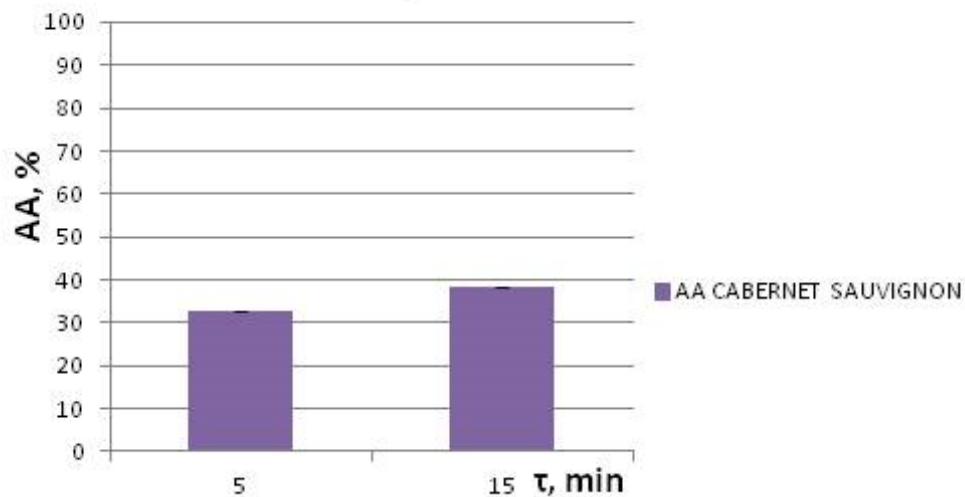

$T E=400.00 \mathrm{mg} / \mathrm{dm}^{3}$

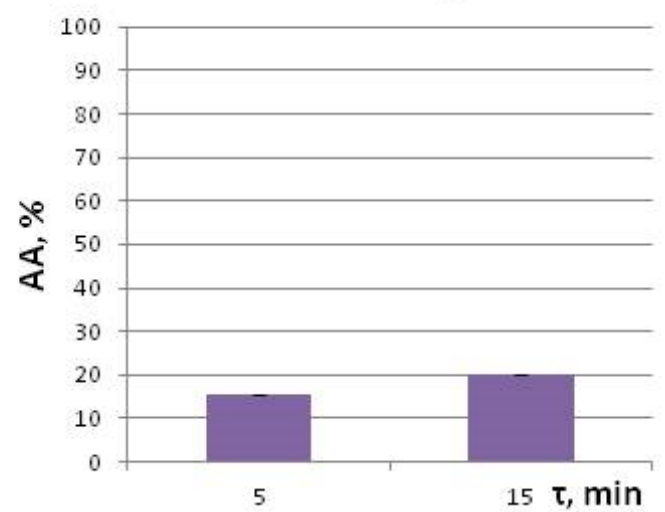

- AA CABERNET SAUVIGNON

Figure 8 Antioxidant activity of red wine of the introduced Cabernet Sauvignon variety at TE $=600.00 \mathrm{mg} / \mathrm{dm}^{3} \mathrm{and} \mathrm{TE}=400.00 \mathrm{mg} / \mathrm{dm}{ }^{3}$

$\mathrm{TE}=600.00 \mathrm{mg} / \mathrm{dm}^{3}$

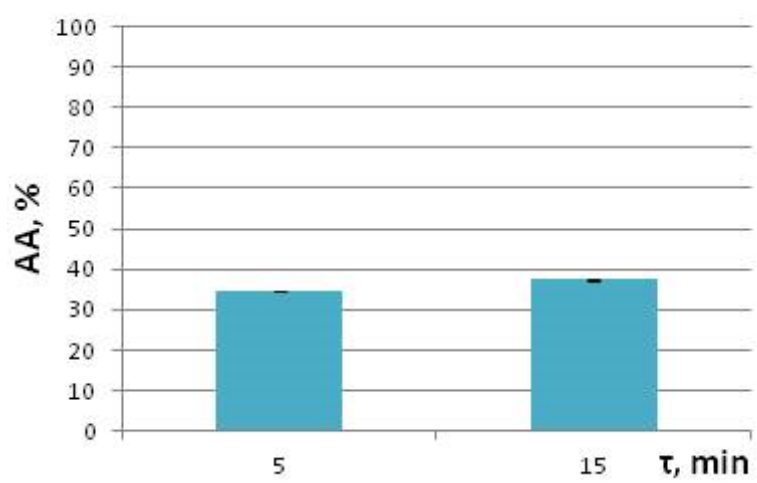

$\mathrm{TE}=400.00 \mathrm{mg} / \mathrm{dm}^{3}$

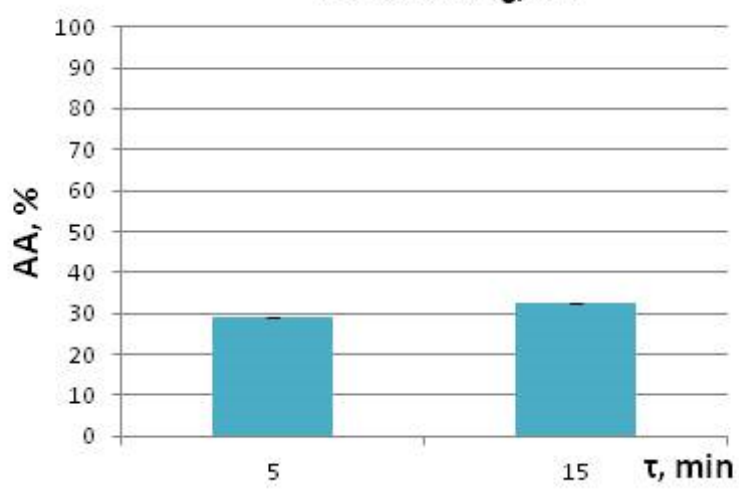

Figure 9 Antioxidant activity of red wine of the local variety Gamza at TE $=600.00 \mathrm{mg} / \mathrm{dm}^{3}$ and TE $=400.00 \mathrm{mg} / \mathrm{dm}$

$T E=600.00 \mathrm{mg} / \mathrm{dm}^{3}$

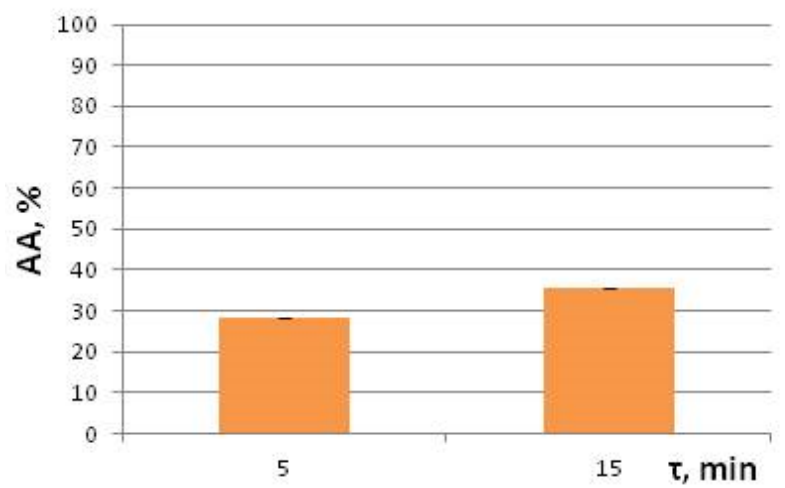

TE $=400.00 \mathrm{mg} / \mathrm{dm}^{3}$

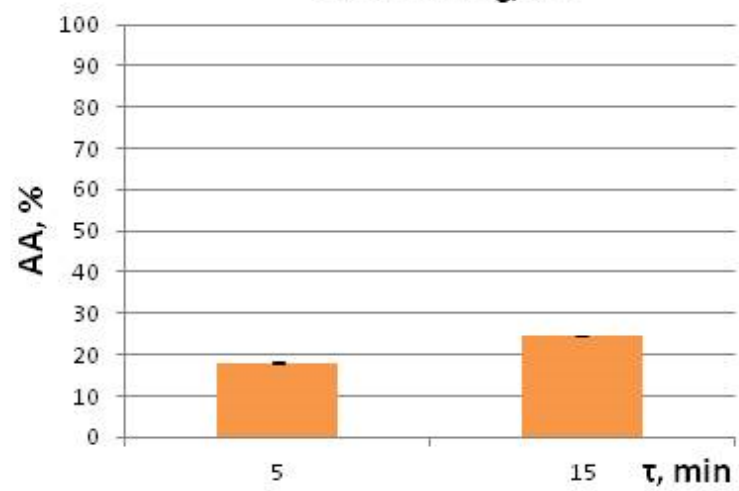

Figure 10 Antioxidant activity of red wine of the hybrid variety Rubin at TE $=600.00 \mathrm{mg} / \mathrm{dm}^{3}$ and TE $=400.00 \mathrm{mg} / \mathrm{dm}$

The highest antioxidant activity in red wines was found in Gamza. At TE $=600.00$ $\mathrm{mg} / \mathrm{dm}^{3}$ and a reaction time of $5 \mathrm{~min}$ it was $34.63 \pm 0.158 \%$. When the reaction time was increased to $15 \mathrm{~min}$, an increase to $37.37 \pm 0.036 \%$ was reported. At TE $=400.00 \mathrm{mg} / \mathrm{dm}^{3}$ at 5 th $\mathrm{min}$ of the reaction anti-radical activity of $29.02 \pm 0.011$ $\%$ was found, and at 15 th min it was higher and reached a value of $32.39 \pm 0.020$ $\%$.

The wine of the introduced control variety Cabernet Sauvignon showed lower antioxidant activity than Gamza, but the difference between them was very small At TE $=600.00 \mathrm{mg} / \mathrm{dm}^{3}$ and a reaction time of $5 \mathrm{~min}$, Cabernet Sauvignon wine showed an antioxidant activity of $32.58 \pm 0.100 \%$. At 15 minutes of the reaction, a higher activity was registered, namely $38.34 \pm 0.025 \%$. At TE $=400.00 \mathrm{mg} / \mathrm{dm}^{3}$, an antioxidant activity of $15.59 \pm 0.107 \%$ was found at 5 minutes of the reaction, and an activity of $20.04 \pm 0.020 \%$ was recorded at 15 minutes for this extract.

Gamza and Cabernet Sauvignon wines showed very similar radical-capturing activity.

The wine of the hybrid variety Rubin showed the lowest antioxidant activity. At $\mathrm{TE}=600.00 \mathrm{mg} / \mathrm{dm}^{3}$, at 5 th $\mathrm{min}$ of the reaction it was $28.38 \pm 0.150 \%$. At 15 th min it increased to $35.42 \pm 0.055 \%$. At TE $=400.00 \mathrm{mg} / \mathrm{dm}^{3}$, a normal decrease in activity was observed, recorded as $18.09 \pm 0.080 \%$ in 5 th min of reaction and increasing to $24.44 \pm 0.047 \%$ in 15 th $\mathrm{min}$.
There was a correlation between the antioxidant activity of red wines and the content of NPC in them, respectively: NPC (AA) Gamza > NPC (AA) Cabernet Sauvignon> NPC (AA) Rubin.

\section{CONCLUSION}

The following conclusions could be made from the study regarding the phenolic composition and antioxidant activity of white and red wines from introduced, local and hybrid grapevine varieties from the region of Central Northern Bulgaria:

- The chemical parameters of the wines were in optimum.

- The white wines of the introduced Chardonnay variety and the local Dimyat showed almost identical TPC content $\left(700.00 \pm 0.0 .000 \mathrm{mg} / \mathrm{dm}^{3}\right.$ and $703.33 \pm$ $5.773 \mathrm{mg} / \mathrm{dm}^{3}$, respectively), higher than that of the Druzhba hybrid. In the red wines this indicator dominated in the wine of the control introduced variety Cabernet Sauvignon $\left(1666.66 \pm 5.773 \mathrm{mg} / \mathrm{dm}^{3}\right)$.

- The highest content of FPC in white wines, in the conditions of Central Northern Bulgaria (harvest 2020), was found in the Chardonnay control wine (769.84 \pm $\left.1.833 \mathrm{mg} / \mathrm{dm}^{3}\right)$. It was lower in Druzhba wine $\left(278.61 \pm 1.251 \mathrm{mg} / \mathrm{dm}^{3}\right)$. The FPC content of red wines dominated in the Rubin hybrid $\left(2532.40 \pm 49.938 \mathrm{mg} / \mathrm{dm}^{3}\right)$. 
- The highest accumulation of NPC in white wines was found in Chardonnay $\left(115.78 \pm 0.325 \mathrm{mg} / \mathrm{dm}^{3}\right)$, while in reds this indicator was dominated in the wine of the local variety Gamza $\left(235.63 \pm 0.498 \mathrm{mg} / \mathrm{dm}^{3}\right)$.

- The established content of anthocyanins in the studied red wines followed the order wine-introduced variety $>$ wine - hybrid variety $>$ wine - local variety.

- The highest antioxidant activity in white wines was found in Chardonnay, and the difference in the percentage of free radical elimination between wines of the local and hybrid variety was small.

- The red wines of Gamza and Cabernet Sauvignon showed a close percentage of radical-scavenging activity, but it was slightly higher in the wine of the local variety Gamza.

- A correlation between the antioxidant activity of red wines and the content of NPC in them was found, respectively: NPC (AA) Gamza > NPS (AA) Cabernet Sauvignon > NPC (AA) Rubin.

- White and red wines from introduced, local and hybrid grapevine varieties from the region of Pleven, Central Northern Bulgaria showed good and balanced phenolic accumulation capacity, resulting in optimal ability for in vitro elimination of free DPPH radicals.

\section{REFERENCES}

Baydar, N., Babalik, Z., Turk, F. \& Cetdn, E. (2011). Phenolic Composition and Antioxidant Activities of Wines and Extracts of Some Grape Varieties Grown in Turkey. Tartm Bilimler i Dergisi - Journal of Agricultural Sciences, 17, 67-76. https://doi.org/10.1501/tarimbil 0000001157

Chobanova, D. (2012). Enology. Part I: Composition of wine. Academic Press of University of Food Technologies, Plovdiv, Bulgaria. (BG)

Hertog, M.G., Kromhout, D., Aravanis, C., Blackburn, H., Buzina, R., Fidanza, F., Giampaoli, S., Jansen, A., Menotti, A., Nedeljkovic, S., Pekkarinen, M., Simic, B.S., Toshima, H., Feskens, E.J.M., Hollman, P.C.H. \& Katan, M.B. (1995) Flavonoid intake and long-term risk of coronary heart disease and cancer in the seven countries study. Archives of Internal Medicine, 155, 381-386. https://doi.org/10.1001/archinte.155.4.381

Ivanov, T. (1981). Technology of wine. Ed. Hristo G. Danov, 573 p. (BG)

Ivanov, T., Gerov, S., Yankov, A., Bambalov, G., Tonchev, T., Nachkov, D. \&

Marinov, M. (1979). Guide to wine technology. Publishing House G. Danov", 530 p. (BG)

Katalinić, V., Milos, M., Modun, D., Music, I. \& Boban, M. (2004). Antioxidant effectiveness of selected wines in comparison with $(+)$-catechin. Food Chemistry, 86, 593-600. https://doi.org/10.1016/i.foodchem.2003.10.007

Li, H, Wang, X., Li, Y., Li, P. \& WANG, H. (2009). Polyphenolic compounds and antioxidant properties of selected China wines. Food Chemistry, 112, 454- 460 https://doi.org/10.1016/j.foodchem.2008.05.111

Marković, M., Martinović Bevanda, A. \& Talić, S. (2015). Antioxidant activity and total phenol content of white wine Žilavka. Bulletin of the Chemists and Technologists of Bosnia and Herzegovina, 44, 1-4.

Nistor, E., Dobrei, A., Dobrei, A., Camen, D., Mălăescu, M. \& Prundeanu, H. (2015). Anthocyanins and phenolics in Cabernet Sauvignon and Pinot noir wines. Journal of Horticulture, Forestry and Biotechnology, 19(1), 226 - 229.

Petkov, G. (1977). Biochemical and technological study of the varieties Bouquet,

Rouen and Rubin for the production of red wines. Dissertation. Institute of Viticulture and Enology, Pleven. (BG)

Radulov, L., Babrikov, D. \& Georgiev, S. (1992). Ampelography with basics of winemaking. Sofia, Zemizdat, p. 187. (BG)

Renaud, S. \& De Lorgeril, M. (1992). Wine, alcohol, platelets, and the French paradox for coronary heart disease. Lancet, 339, 1523-1526. https://doi.org/10.1016/0140-6736(92)91277-f

Roychev, V. (2012). Ampelography. Plovdiv, Academic Publishing House of the University of Plovdiv, p. 576. (BG)

Shadidi, F. \& Naczk, M. (1995). Food Phenols: Source, Chemistry, Effects and Applications. Technomic Publishing Company (USA), pp. 331 https://doi.org/10.1016/s0308-8146(96)80478-x

Srivastava, K. \& Kumar, K. (2015). Stress, Oxidative Injury and Disease. Indian Journal of Clinical Biochemistry, 30(1), 3-10. https://doi.org/10.1007/s12291-0140441-5

Sweet, N. (2007). Chardonnay History and Selections at FPS. FPS Grape Program Newsletter, 20-36.

Sweet, N. (2008). Cabernet Sauvignon at FPS. FPS Grape Program Newsletter, 16-32.

Velkov, E. (1996). Encyclopedia of alcoholic beverages. "Poligrafia" Ltd., Plovdiv, Bulgaria, 1996, ISBN 954-698-002-1 (BG).

Wang, H., Cao, G. \& Prior, R.L. (1996). Total antioxidant capacity of fruits Journal of Agriculture and Food Chemistry, 44(3), 701-705. https://doi.org/10.1021/jf950579y

Waterhouse, A.L. (2002). Wine Phenolics. Annals of New York Academy of Science, 957, 21-36. https://doi.org/10.1111/j.1749-6632.2002.tb02903.x

Yankov, A. (1992). Winemaking Technology. Sofia, Zemizdat, 355 pp. (BG). 